\title{
Mit aktu mowy jako kategorii organizacji analizy pragmatycznej
}

\section{Piotr Cap}

Uniwersytet Łódzki

strus_pl@yahoo.com

\section{Streszczenie}

W tym krótkim artykule sygnalizuję ograniczenia teorii aktów mowy postrzeganej jako element porządkujący analizy pragmatycznej. Przyznają, że pojęcie aktu mowy pomaga $w$ usystematyzowaniu i uogólnieniu analizy na poziomie danego, pojedynczego wypowiedzenia, wskazuję, że potencjał ów jest znacznie mniejszy na poziomie dyskursu. Powodem tego jest względność pojęcia intencji wyrażanej aktem mowy, która rośnie wraz z każdym kolejnym, coraz wyższym szczeblem.

Słowa kluczowe:| teoria aktów mowy, Austin, poziom mikropragmatyczny, poziom makropragmatyczny

\author{
Abstract \\ Myth of Speech Act as a Controlling Category in Pragmatic Analysis
}

In this short article I point to the limitations of the theory of speech acts, perceived as the controlling element of pragmatic analysis. While admitting that the concept of speech act helps systematize and generalize the analysis at the level of a given, individual utterance, I indicate that such a potential is considerably weaker at the level of discourse. The reason for such a discrepancy is the relativity of the concept of intention expressed by speech act, which grows as the analysis moves upwards.

Keywords: speech act theory, Austin, micropragmatic level, macropragmatic level 


\section{Analiza na poziomie mikropragmatycznym (wyrażenia)}

Teoria aktów mowy (Austin 1962, Searle 1975 oraz bardzo liczne późniejsze modyfikacje, por. przegląd tychże w Tsohatzidis 1994, Post 2001, Horn i Ward 2004, Kalisz 2006, Huang 2007, itp.) należy do najczęściej dyskutowanych zagadnień pragmatyki językowej. Jej popularność wynika w dużym stopniu z faktu, iż nie sposób analizować akty mowy bez jednoczesnego, choćby pośredniego odniesienia do innych pojęć pragmatycznych, takich jak deiksa, presupozycja czy implikatura. Dodatkowo, analizy aktów mowy często lokują je mniej lub bardziej świadomie - w pozycji nadrzędnej w stosunku do innych pojęć. Na poziomie „mikropragmatycznym” (czyli zamykającym się w obrębie intencji i efektu konkretnego wyrażenia; por. Mey 2001) takie podejście ma swoje uzasadnienie. Rozważmy następujący przykład:

(1) Wy sobie nie myślcie, że każdy musi zaliczyć te zajęcia.

Załóżmy, że analityk ma dostęp do następujących danych kontekstowych a.-f. i (jedynie) w oparciu o nie określa intencję (,silę illokucyjną”) a także oczekiwany efekt (,,perlokucyjny”) wyrażenia (1):

a. nadawcą (1) jest nauczyciel akademicki znany z liberalnego podejścia do rozliczania studentów z nabywanej wiedzy;

b. (1) wypowiedziane jest w trakcie zajęć o charakterze wykładu;

c. zajęcia te są obowiązkowe, ale wykładowca rzadko sprawdza listę obecności;

d. (zapewne m.in. w związku z c.) na zajęcia regularnie uczęszcza jedna trzecia $\mathrm{z}$ zapisanych na nie studentów;

e. (1) zostało wypowiedziane bezpośrednio po tym, jak trójka studentów przyszła na wykład z 20-minutowym opóźnieniem.

f. Sytuacja opisana w e. ma miejsce po raz pierwszy.

Spekulacje na temat aktu mowy (rozumianego w kategoriach pochodnej treści, intencji i możliwego/oczekiwanego efektu) zawartego w (1) obracają się niejako nieuchronnie wśród wymienionych wcześniej pojęć ,,podrzędnych” - deiksy, presupozycji i implikatury. Analityk ocenia w jaki sposób treść wyrażenia przekazana jest na poziomie leksykalnym i 
strukturalnym (analiza pozapragmatyczna), do jakich elementów kontekstu wyrażenie się odwołuje i jak te elementy są leksykalizowane (obszar ,roboczy” deiksy), jakie założenia mogły zostać poczynione przez nadawcę, w świetle danych a.-f., zanim (1) zostało wypowiedziane (obszar presupozycji) oraz jaki efekt może wywołać to wyrażenie (obszar implikatury) - w kontekście wszystkich do tego momentu przeanalizowanych uwarunkowań. Ocena ta ma więc charakter kontinuum (odzwierciedlającego również równoległe kontinuum czasowe), łączącego rozważania na temat uwarunkowanej kontekstem intencji nadawcy, z rozważaniami dotyczącymi ostatecznego efektu wyrażenia. Wynikiem oceny jest nadanie wyrażeniu (1) odpowiedniej etykiety teoretycznej, tj. określenie (1) danym aktem mowy.

Oto jak może w praktyce przebiegać analiza (1). Skoro wykładowca bywał dotąd „liberalny” w stosunku do studentów a treść (1) na to nie wskazuje, należy przyjąć, że wypowiedzenie (1) zostało sprowokowane konkretnym zdarzeniem i - w świetle danych kontekstowych - za takie trzeba uznać pojawienie się studentów na wykładzie z 20minutowym opóźnieniem. W myśl w/w rozumowania (które samo w sobie ma charakter inferencji niemal identycznej $\mathrm{z}$ inferencjami implikatur wyprowadzanych $\mathrm{z}$ łamania maksymy relewancji - (1) jest jawnie nierelewantne $\mathrm{w}$ stosunku do oczekiwań dyskursywnych) należy dalej przyjąć, że (1) zawiera znaczący ładunek emocjonalny - co zresztą potwierdza zwrot ,na ty” - który określa status deiktyczny takich elementów jak „Wy” i „każdy”. Analityk ma prawo postulować, że nadawca nie przyjmuje „słabszego” odniesienia (szczególnie jeśli chodzi o „każdy”), w stosunku do adresata ogólnego, lecz „mocniejsze” - ukierunkowane na tych konkretnych studentów, którzy się spóźnili.

Oczywiście nie sposób wykluczyć wielce prawdopodobnej intencji nadawcy w postaci dania przykładu ogólnemu odbiorcy poprzez napiętnowanie odbiorcy konkretnego, ale to tylko potwierdza związek pomiędzy analizą relacji deiktycznych i implikatury. W taką analizę wplatają się również rozważania na temat presupozycji. Nadawca może zakładać, że wyrażenie (1) osiągnie efekt dyscyplinujący, ponieważ dotąd nie posuwał się do przekazywania tak radykalnych treści, mimo posiadania powodów. Wprowadza on zatem do dyskursu na linii wykładowca-student element emfatyczny, o prawdopodobnie znacznym stopniu oddziaływania na adresata. W sumie więc analityk ma prawo przyjąć, że (1) wyraża (pośredni) akt mowy napomnienia (etykieta „ostrzeżenia” nie korelowałoby jednak z wcześniejszymi liberalnymi praktykami wykładowcy). Etykieta „napomnienia” została nadana $\mathrm{w}$ wyniku analizy (jedynie pokrótce tu zademonstrowanej) obejmującej rozważania na linii intencja-efekt, odnoszące się do obszarów pojęciowych deiksy, presupozycji i implikatury. 
Oczywiście modyfikacja praktycznie którejkolwiek z danych a.-f. doprowadziłaby do przyporządkowania wyrażeniu (1) innej funkcji - mniej lub bardziej pokrewnej z funkcją napomnienia. Gdyby sytuacja opisana w e. miała miejsce po raz kolejny, analityk otrzymałby bodziec do zastanowienia się, czy nie lepszym określeniem funkcji byłoby „ostrzeżenie”. Modyfikacja funkcji czy też postulowanego typu aktu mowy mogłaby zaistnieć również w wyniku zastosowania przez analityka posiadanej wiedzy własnej na temat, na przykład, odczuć wykładowcy związanych z miernym stopniem zainteresowania studentów wykładami. Odczucia określane mianem „frustracji” sprzyjałyby zapewne przyjęciu optyki „napomnienia”, zaś odczucia bardziej radykalne, gniewu, itp., sprzyjałyby określeniu funkcji jako „ostrzeżenia”. Tego typu zmiany w obrębie danych kontekstualnych oraz wiedzy własnej analityka w niczym nie zmieniają samego procesu analizy w kontekście interakcji pojęciowej deiksy, presupozycji czy implikatury. Wszystkie te pojęcia byłyby nadal zaangażowane, składnikowo, w indukcyjny proces wygenerowania kategorii nadrzędnej opisu, tj. aktu mowy przekazywanego w wyrażeniu.

Postulat nadrzędności (teoretycznej i metodologicznej) aktu mowy w stosunku do deiksy, presupozycji i implikatury wydaje się również wynikać ze stosunkowo prostej obserwacji dotyczącej zakresu objaśniającego i hierarchiczności pojęć pragmatycznych pojedynczy akt mowy może być „realizowany” lub „generowany” poprzez analizę sieci relacji zawierającej $n$ elementów deiktycznych, $n$ presupozycji, $n$ implikatur, itd. W (1) mamy do czynienia z trzema elementami deiktycznymi, tj. „Wy”, „każdy”, „te”, licznymi założeniami przez nadawcę wiedzy wspólnej dla nadawcy i adresata (liberalne zachowania nauczyciela, mała popularność zajęć, formalny charakter zajęć (wykład) i wiele innych założeń warunkujących wypowiedzenie) oraz - mimo wszystko - różnymi możliwościami interpretowania stopnia radykalności (i konsekwencji) wypowiedzenia. Jednak wszystkie te elementy pełnią dla analityka rolę równoprawnych, składnikowych wskazówek co do tego, jaki akt mowy ma w istocie miejsce i jaka pojedyncza etykieta opisowa byłaby dla niego najodpowiedniejsza.

Załóżmy więc, że (1) zostało ocenione jako akt napomnienia, jednak wyobraźmy sobie również, że wykładowca nie uznaje (1) za wystarczające dla osiągnięcia celu (czyli zdyscyplinowania studentów) i jest zmuszony sięgnąć, ciągle w trakcie tego samego wykładu, po dodatkowe środki językowe, które ów cel w jego rozumieniu ostatecznie zapewnią. Przyjmijmy zatem, że, w pewnych odstępach czasowych (np. pięciominutowych), już po wypowiedzeniu (1), wykładowca stosuje następujące dwa wyrażenia: 
(2) Większość moich Kolegów oblewa studentów za nieobecności na wykładach.

(3) Przyrzekam Wam, że zacznę brać przykład z dr Kowalskiego i będę sprawdzać listę.

Zauważmy, że choć (1), (2) i (3) sprzyjają osiągnięciu tego samego dalekosiężnego celu (zdyscyplinowaniu studentów), (2) i (3) kontrybuują do niego w oparciu o inne akty mowy niż akt dyrektywny (napomnienie) zawarty w (1). Z typologicznego punktu widzenia, (2) wyraża akt asercji, zaś (3) wyraża akt zobowiązania (ang. commissive). Problem polega na tym, że cel można definiować zarówno na poziomie pojedynczego aktu mowy, w kontekście relacji intencja-efekt, ale także na poziomie wyższym i rozleglejszym czasowo. Mówiąc zatem o celu zdyscyplinowania studentów, obracamy się jednocześnie w kontekście aktu mowy napomnienia działającego stosunkowo doraźnie, jak i w kontekście tegoż samego aktu mowy (napomnienia), lecz o działaniu znacznie bardziej dalekosiężnym i potencjalnie podlegającym wspomożeniu przez inne akty mowy (asercja, zobowiązanie (które de facto jest groźbą)). Rozgraniczenie między efektem aktu mowy (nawet o jednolitej etykiecie takiej jak np. napomnienie) w kontekście „doraźnym” i „dalekosiężnym” jest niemożliwe.

Akt mowy może spełniać funkcję porządkującą w stosunku do pojęć składnikowych, jednak jego orientacja przeciwna - tj. stopień wkładu w realizację intencji globalnych - jest trudna do uchwycenia. Efekt zdyscyplinowania studentów może być powiązany z pojedynczym aktem lub też z serią aktów mowy; nie sposób określić ile pojedynczych aktów mowy (takich jak (2) lub (3)) mogłoby się „dokleić” do aktu wyjściowego na rzecz realizacji intencji nadawcy w dłuższej perspektywie czasowej. Przyjrzyjmy się zatem w dalszej części artykułu relacji pomiędzy pojedynczym aktem mowy a serią aktów, podporządkowanych temu samemu dalekosiężnemu celowi.

\section{Analiza na poziomie makropragmatycznym (dyskursu)}

Ta sekcja artykułu wiernie nawiązuje do moich własnych praktyk akademickich, które po części odzwierciedlają zachowanie wykładowcy - autora wyrażeń (1), (2), (3). Rzadko kiedy zaczynam seminarium od sprawdzenia listy obecności. Zamiast tego, często pytam:

4) Witam, jesteśmy wszyscy? 
tworząc tym samym dwa akty mowy bezpośrednie (przywitania i zapytania), a także pośredni akt prośby o poinformowanie mnie o nieobecnych. Akty te wykorzystują elementy deiktyczne (np. “wszyscy”), tworzone są w oparciu o określone presupozycje (np. założenie, że nie wszyscy studenci mogą być obecni w tym momencie na zajęciach), zaś pośredni akt prośby niejako zmusza adresata do przeprowadzenia procesu inferencji. Można przyjąć, że tak właśnie wygląda - w pewnym uproszczeniu - analiza składnikowa aktów mowy wyrażenia (4).

Jako autor tego wyrażenia, mam jednak przywilej stwierdzenia z absolutną pewnością, iż jego funkcja wykracza nieraz daleko poza akt przywitania, zapytania, czy prośby. (4) - lub też wyrażenia semantycznie i pragmatycznie podobne (por. „dzień dobry, chyba już wszyscy jesteśmy, prawda?”, itp. itd. - pojawiają się w tej konkretnej sytuacji (tj. rozpoczęcia seminarium) na tyle często, że można uznać je za elementy rutynowe, podporządkowane większej (narzucałoby się „globalnej” ale to określenie rezerwuję dla opisu makro aktu mowy poniżej) intencji. Zwróćmy uwagę na następującą analogię: jeśli codziennie rano wychodzę do kiosku po gazetę (co stanowi zdarzenie złożone z serii mikro-zdarzeń analogicznych w swojej składnikowej funkcji w stosunku do pojedynczych aktów mowy opisanych w (4)), za moją „większą intencję" uznać można długofalową chęć orientowania się w bieżących wydarzeniach (relacjonowanych w gazecie). Analogia ta każe nam zaakceptować popularne u teoretyków aktów mowy przekonanie o związku pojęciowym pomiędzy zdarzeniem fizycznym a aktem mowy i, co za tym idzie, szukać w (4) składników realizacji większej intencji.

Poszukiwania te prowadzą do wniosku, że „większą intencją” determinującą (4) jest rozpoczęcie seminarium, które możliwe jest tylko po uprzednim sprawdzeniu warunków dla realizacji powiązanego z intencją celu przeprowadzenia produktywnych zajęć. Nie jest to wielce oryginalna konkluzja, ale stanowi jasny i wygodny punkt odniesienia dla rozważań na temat natury intencjonalności i sposobów jej wyrażania w języku. Już w tym momencie widzimy, że natura ta jest skomplikowana i wykracza poza kontekst pojedynczego wypowiedzenia, a zatem wymaga poszerzenia aparatu badawczego. Aparat ten miałby za zadanie opis intencjonalności na poziomie dyskursu.

Niewątpliwie łatwo wyobrazić sobie sytuację, w której wypowiedzenie (4) nie wystarcza do skutecznego rozpoczęcia seminarium i istnieje potrzeba „wsparcia” go dodatkowymi wyrażeniami. Wyrażenia te abstrahowane są z nieskończonego zbioru wyrażeń zdolnych realizować, w mniejszym lub większym stopniu, w/w (,,większą”) intencję. Oto kilka z nich: "Robi się późno", “Czy mogę prosić o zamknięcie drzwi?”, "Panie Adamie, proszę o 
uwagę!", "No dobrze, zatem już zaczniemy”, “Znów zabrakło pisaków do tablicy!”, "Nie pamiętam, kiedy ostatnio zaczęliśmy punktualnie", etc. Wszystkie te na pozór różne wyrażenia mogą wnosić określony wkład w realizację zasadniczej intencji. Zauważmy, że wkład ten wnoszony jest przez wypowiedzenia zawierające formalnie różne akty mowy (asercje, dyrektywy, akty ekspresywne), o bezpośredniej lub pośredniej sile illokucyjnej. Z kolei, patrząc „w dół” całej struktury, każdy z tych aktów może charakteryzować się osobną kompozycją składników deiktycznych, presupozycji i implikatur.

Tworzenie przez nadawcę pojedynczych aktów mowy (z których każdy charakteryzuje się odrębną kompozycją składników mikropragmatycznych) podporządkowanych intencji nadrzędnej doczekało się anglojęzycznej etykiety speech event, którą można na język polski przetłumaczyć jako seryjny akt mowy ${ }^{1}$. Seryjny akt mowy może, zgodnie z powyższą charakterystyką, rozciągać się na potencjalnie nieskończona liczbę wyrażeń, w zależności od tego, ile z nich potrzeba dla zrealizowania nadrzędnej intencji. Jeśli na przykład studenci mojej grupy seminaryjnej wchodzą do sali dyskutując żywo o dopiero co zakończonym egzaminie, w którym uczestniczyli, przygotowanie warunków dla rozpoczęcia seminarium może wymagać użycia stosunkowo dużej liczby wypowiedzeń. W innym wypadku kilka krótkich uwag, najczęściej o charakterze technicznym, wystarczy by przejść do meritum tzn. rozpocząć merytoryczną część zajęć. Długość „dyskursu wprowadzającego” jest więc warunkowana kontekstem pozajęzykowym. Należy podkreślić ponownie, że seryjny akt mowy może podporządkowywać sobie taką liczbę wyrażeń (i pojedynczych aktów mowy w nich zawartych) jaka konieczna jest dla sprostania wymaganiom kontekstu. Wyrażenia te nie muszą koniecznie układać się w strukturę monologu. Tworząc warunki dla rozpoczęcia seminarium wypowiadam nieraz kilka zdań pod rząd, robię pauzę, czasem odpowiadam na pytanie lub pytania, które pojawia się spontanicznie, a następnie powracam do monologu. Moje zachowanie jest więc typowym zachowaniem dyskursywnym, wpasowującym się w określony kontekst interpersonalny, społeczny i reagującym elastycznie na rozwój uwarunkowań tego kontekstu.

Przywołane wcześniej pojęcie nieskończoności powraca do dyskusji, jeśli ukierunkujemy ją na kwestię ewentualnego istnienia intencji “supernadrzędnej”, której podporządkowane byłyby większe grupy seryjnych aktów mowy (analogicznie do hierarchii „akt mowy” - „seryjny akt mowy”, tylko tym razem na jeszcze wyższym (ostatecznym?) poziomie struktury intencjonalności). Intrygujące jest spostrzeżenie, że w przykładzie (4) seryjny akt mowy, który realizuje intencję rozpoczęcia seminarium w oparciu o elementy składowe (indywidualne akty mowy), sam może jawić się jako element składowy podrzędny 
dla osiągnięcia jeszcze szerszego i bardziej dalekosiężnego celu, np. udanego przeprowadzenia seminarium w całości. Realizacja takiego celu wiąże się z zaistnieniem potencjalnie nieskończonej liczby seryjnych aktów mowy, których intencje obejmują czasokres od rozpoczęcia seminarium do jego zakończenia. Przykładowymi intencjami mogą być chęć wyjaśnienia problemu merytorycznego, który wyniknął w trakcie zajęć, bądź też chęć zadania pracy domowej. Seryjne akty mowy wyrażające te dwie intencje mogą oczywiście, zgodnie ze swą opisaną wyżej naturą, zawierać akty składowe takie jak np., w drugim z przytoczonych przypadków, akt ekspresywny (udzielenie studentom reprymendy za niezadowalające wykonanie poprzedniego zadania domowego), akt zobowiązania (ang. commissive; wyrażenie groźby nie zaliczenia zajęć w przypadku dalszego zaniedbywania prac domowych), akt dyrektywny (polecenie wykonania nowego zadania (i/lub ponownego wykonania zadania bieżącego) na kolejne seminarium), akt asercji (opis treści i celu zadania), itp. Zróżnicowanie i liczba tych pojedynczych aktów mowy są nie mniejsze niż miało to miejsce w przypadku aktów składających się na seryjny akt mowy rozpoczęcia seminarium.

W ten sposób wszelkie dotychczasowe rozważania zaprowadziły nas, drogą na wskroś indukcyjną, na szczyt swoistej "piramidy intencjonalności”. Przychodzi nam w tym miejscu zadać pytanie o możliwość istnienia „supernadrzędnej”, „globalnej” kategorii wyrażania intencji, konstruktu, który byłby zdolny objąć swym zakresem opisu wszystkie intencje realizowane w ramach składowych seryjnych aktów mowy, a więc pośrednio także wszystkie intencje realizowane $\mathrm{w}$ ramach aktów mowy indywidualnych. Pytanie to stawia de facto (choć nie bezpośrednio) klasyczna teoria makro aktu mowy autorstwa Van Dijk'a. Teoria ta zakłada istnienie globalnego aktu mowy wyrażanego poprzez cały dyskurs, obejmujący sekwencje rozmaitych aktów mowy ${ }^{2}$ Jej niewątpliwą zaletą jest stosunkowo udana próba systematyzacji podejścia do seryjnych aktów mowy jako komponentów pewnego globalnego „makro aktu”. Jednak już samo doprecyzowanie pojęcia tegoż makro aktu nastręcza trudności i wykazuje nieuchronną względność oceny czym właściwie jest ów “cały dyskurs” i jakie są jego granice.

Czy zatem przypadek (4) odnosimy np. do wszelkich zachowań dyskursywnych w ramach czasowych trwania tego konkretnego seminarium? Jeśli tak, to ta dana relacja hierarchiczna MAKRO AKT - SERYJNE AKTY MOWY - (INDYWIDUALNE) AKTY MOWY wygląda sama w sobie logicznie, a jej aparat opisu wydaje się metodologicznie poprawny. Relacja ta ignoruje jednak oczywisty potencjał postulowanego makro aktu (wyrażającego intencję przeprowadzenia udanego seminarium) łączenia się z ... kolejnymi makro aktami, na rzecz wyrażenia jeszcze „rozleglejszej”, jeszcze „,bardziej nadrzędnej” 
intencji. Intencja przeprowadzenia udanego seminarium może być przecież częścią składową intencji sprawnego przeprowadzenia całego semestralnego kursu, co z kolei stanowi wpisuje się w intencję odpowiedniego wykonywania wszystkich obowiązków akademickich, itp. itd. Równolegle akumulują się kolejne, coraz rozleglejsze makro akty mowy wyrażające owe intencje. Ustalenie „supernadrzędnej” intencji, wyrażonej w ramach „supernadrzędnego” makro aktu mowy wydaje się w tej sytuacji przedsięwzięciem nie tyleż nawet filozoficznym, co po prostu niemożliwym do wykonania.

Nie znaczy to jednak, że należy lekką ręką zbywać w/w próby, uznając teorie w typie modelu makro aktu mowy Van Dijk'a za kompletnie pozbawione wartości poznawczej. Niewątpliwą choć nieco paradoksalną zaletą poszukiwań ściśle zdefiniowanych poziomów w hierarchii wyrażania intencjonalności w języku jest moim zdaniem wykazanie ograniczeń takich przedsięwzięć oraz - w konsekwencji - skierowanie uwagi analityków na bardziej wymierzalne aspekty i wyraźniej wygraniczone terytoria użycia języka niż „cały dyskurs”. Od co najmniej dwóch dekad jesteśmy świadkami rozkwitu Analizy Konwersacyjnej (ang. Conversation Analysis; $C A$ ), która istotnie - co podnoszą krytycy ${ }^{3}$ - operuje w obrębie ograniczonych kontekstów pozajęzykowych, jednakże wykształciła szereg cennych pojęć, które przeniknęły już nie tylko do aparatu pragmatyki językowej, ale wręcz językoznawstwa w ogóle. Mam tu na myśli choćby "miejsce przekazania głosu” (ang. transition relevance place) czy też "pary przyległe" (ang. adjacency pairs), terminy wykorzystywane często poza AK, w socjolingwistyce czy też lingwistyce stosowanej. Poza tym, już samo postawienie pytania o intencję "nadrzędną" czy "globalną" jest metodologicznie cenne, ponieważ zmusza analityka do rozważań dotyczących wyrażania intencjonalności w obrębie dłuższego okresu czasu. Pochodną takiego podejścia mogą być (i są) modele „kompensacyjne” tzn. zajmujące się kwestią utrzymywania realizacji danej intencji w rozległym czasokresie, w którym pewne składniki wyrażania intencji naturalnie wymierają i muszą być zastąpione składnikami innymi. Modele te szczególnie często budowane są w dziedzinie tzw. Krytycznej Analizy Dyskursu (ang. Critical Discourse Analysis), a ich przykładem mogą być teoria modalności dyskursu Chiltona (2004) lub też model legitymizacji dyskursu politycznego (Cap, 2008).

\section{Uwagi końcowe}

W niniejszym szkicu starałem się zwrócić uwagę na niejednoznaczny status aktu mowy jako kategorii porządkującej $\mathrm{w}$ analizie pragmatycznej. Kategoria ta sprawdza się na poziomie indywidualnego wypowiedzenia oraz przy orientacji analizy „w dół”, tj. dla 
wyszczególnienia częściowo zleksykalizowanych elementów składowych (vide deiksa, presupozycja semantyczna, implikatura konwencjonalna) wyrażania intencji w tymże wypowiedzeniu. Zawodzi jednak przy orientacji analizy „do góry”, kiedy od poziomu pojedynczego wyrażenia przechodzimy na poziom serii powiązanych ze sobą kontekstowo wyrażeń, czyli dyskursu. Analiza aktu mowy na poziomie dyskursu wiąże się z nieuchronną relatywizacją zakresu intencji wyrażanej tym aktem, co stanowi zasadniczą przyczynę niepowodzenia.

\section{Źródło}

Tekst ten został po raz pierwszy opublikowany w roku 2010 [w:] Joanna Nijakowska (red.), Interdyscyplinarne studia nad świadomościa $i$ przetwarzaniem językowym, Język $i$ komunikacja 29. Kraków: Tertium; 225-235.

\section{Przypisy}

\footnotetext{
${ }^{1}$ Tłumaczenie to moim zdaniem trafniej określa naturę intencjonalności złożonej, niż czyni to anglojęzyczny oryginał. Mamy wszak do czynienia nie z konkretnym „wydarzeniem” (event) lecz serią zdarzeń odzwierciedlonych w serii aktów mowy. Wydaje się, że literatura anglojęzyczna od dawna miała i ma kłopot z precyzyjnym nazwaniem opisywanego zjawiska i stąd pojawiają się różne propozycje. Choć szeroko cytowany Mey (1993, 2001) mówi o speech events, równie popularny Levinson (1983) przyjmuje nomenklaturę 'activity type' (,typ działalności”??) a z kolei Grundy (1995) proponuje po prostu 'genre’ (dosłownie „rodzaj”, ale chyba lepiej brzmiałoby ,gatunek” (mowy)).

2 Por. Van Dijk (1977, 1980), a także Van Dijk i Kintsch (1983).

${ }^{3}$ Zobacz przegląd prac Sacksa, Schegloffa, Jeffersona, Pottera i innych, a także ich krytykę, w Ten Have (2007).
}

\section{Bibliografia}

Austin, John (1962) How to Do Things with Words. Oxford: Oxford University Press.

Cap, Piotr (2008) "Towards the Proximization Model of the Analysis of Legitimization in Political Discourse". Journal of Pragmatics, 40; 17-41.

Chilton, Paul (2004) Analysing Political Discourse: Theory and Practice. London: Routledge. Grundy, Peter (1995) Doing Pragmatics. London: Edward Arnold.

Horn, Laurence, Gregory Ward (2004) The Handbook of Pragmatics. Oxford: Blackwell. Huang, Yan (2007) Pragmatics. Oxford: Oxford University Press. 
Kalisz, Roman (2006) „Językoznawstwo kognitywne w analizie pragmatyki językowej”. [W:] Piotr Stalmaszczyk (red.) Metodologie Językoznawstwa. Łódź: WUŁ; 234-250.

Levinson, Stephen (1983) Pragmatics. Cambridge: Cambridge University Press.

Mey, Jacob L. (1993) Pragmatics. Oxford: Blackwell.

Mey, Jacob L. (2001). Pragmatics. $2^{\text {nd }}$ edition. Oxford: Blackwell.

Post, Michał (2001) „Efekty i akty perlokucyjne”. [W:] Wojciech Kubiński, Danuta Stanulewicz (red.), Językoznawstwo Kognitywne II. Zjawiska Pragmatyczne. Gdańsk: WUG; 135-147.

Searle, John (1975) “A Taxonomy of Speech Acts”. [W:] K. Gunderson (red.) Minnesota Studies in the Philosophy of Science, 9; 344-69.

Ten Have, Paul. 2007. Doing Conversation Analysis. A Practical Guide. Thousand Oaks: Sage.

Tsohatzidis, Savas (red.) (1994) Foundations of Speech Act Theory: Philosophical and Linguistic Perspectives. London: Routledge.

Van Dijk, Teun (1977) Text and Context. London: Longman.

Van Dijk, Teun (1980) Macrostructures. An Interdisciplinary Study of Global Structures in Discourse, Interaction, and Cognition. Hillsdale, NJ: Erlbaum.

Van Dijk, Teun, Walter Kintsch (1983) Strategies of Discourse Comprehension. New York: Academic Press. 